\title{
VIRULENCE OF ENTOMOPATHOGENIC NEMATODES (RHABDITIDA: STEINERNEMATIDAE AND HETERORHABDITIDAE) FOR THE CONTROL OF Diabrotica speciosa GERMAR (COLEOPTERA: CHRYSOMELIDAE)
}

\author{
Virulência de nematoides entomopatogênicos (Rhabditida: Steinernematidae e \\ Heterorhabditidae) para o controle de Diabrotica speciosa Germar (Coleoptera: Chrysomelidae)
}

\author{
Viviane Santos ${ }^{1}$, Alcides Moino Junior ${ }^{2}$, Vanessa Andalón ${ }^{2}$, Camila Costa Moreira ${ }^{3}$, Ricardo Alves de Olinda ${ }^{4}$
}

\begin{abstract}
Entomopathogenic nematodes (EPNs) are used in biological control of soil insects and show promise in the control of $D$. speciosa. The objective of this work was to evaluate the potential of native and exotic entomopathogenic nematode isolates in the control of D. speciosa under laboratory and greenhouse conditions. Results showed that all of EPNs caused larval mortality. The most virulent were Heterorhabditis sp. RSC01 (94\%), Steinernema glaseri (84\%), Heterorhabditis sp. JPM04 (82\%) and Heterorhabditis amazonensis RSC05 (78\%). There was no effect of the Heterorhabditis sp. RSC01 and S. glaseri isolates on eggs. The maximum mortality of D. speciosa larvae by Heterorhabditis sp. RSC01 was observed at a concentration of $300 \mathrm{IJ} / \mathrm{insect}$, while by S. glaseri observed the highest mortality at the concentration of $200 \mathrm{IJ} /$ insect. The Heterorhabditis sp. RSC01 isolate caused over $80 \%$ pupal mortality at a concentration of $250 \mathrm{IJ} /$ insect. The virulence of Heterorhabditis sp. RSC01 and S. glaseri was affected by temperature. The Heterorhabditis sp. RSC01 isolate caused reduction in larva survival under greenhouse conditions at all of the tested concentrations and there was no difference in mortality among different concentrations of infectid juveniles.
\end{abstract}

Index terms: Steinernema, Heterorhabditis, crisomelid beetle, pathogenicity.

\section{RESUMO}

Os nematóides entomopatogênicos são utilizados no controle biológico de pragas de solo, e são promissores para o controle de D. speciosa. Neste trabalho, objetivou-se avaliar o potencial de espécies nativas e exóticas de isolados de nematóides entomopatogênicos para o controle de D. speciosa, em condições de laboratório e de casa de vegetação. Verificou-se que todos os nematóides causaram mortalidade larval. Os mais virulentos foram Heterorhabditis sp. RSC01 (94\%), Steinernema glaseri (84\%), Heterorhabditis sp. JPM04 (82\%) e Heterorhabditis amazonensis RSC05 (78\%). Não houve efeito dos isolados Heterorhabditis sp. RSC01 e S. glaseri em ovos. A mortalidade máxima de larvas de D. speciosa por Heterorhabditis sp. RSC01 foi observada na concentração de $300 \mathrm{JI} /$ inseto, enquanto para S. glaseri a maior mortalidade foi obervada na concentração de $200 \mathrm{JI} /$ inseto. O isolado Heterorhabditis sp. RSC01 causou mais de 80\% de mortalidade de pupas na concentração de $250 \mathrm{IJ} /$ inseto. A virulência de Heterorhabditis sp. RSC01 e S. glaseri foi afetada pela temperatura. $\mathrm{O}$ isolado Heterorhabditis sp. RSC01 causou redução na sobrevivência da larvas em casa de vegetação em todas as concentrações de juvenis infectantes testadas e não houve diferença na mortalidade entre os diferentes tratamentos.

Termos para indexação: Steinernema, Heterorhabditis, crisomelídeo, patogenicidade.

(Received in may 12, 2011 and approved in september 9, 2011)

\section{INTRODUCTION}

The chrysomelid Diabrotica speciosa Germar (Coleoptera: Chrysomelidae) has been causing great concern to farmers, due to its wide occurrence and polyphagous habit. The adults feed preferentially on leaves, shoots, fruits and pollen of cultivated and wild plants, while the larvae prefer the roots. In early attacks on maize, the larvae of $D$. speciosa can bore into the caulicle of the seedlings, causing drying and death of central leaves. In more developed plants however, they prefer to feed on adventitious roots (GASSEN, 1989). There are few works looking at the use of biological control agents to suppress populations of $D$. speciosa at this stage; so control has is done exclusively through the use of chemical products.

Entomopathogenic nematodes (EPNs) of the Steinernematidae and Heterorhabditidae families (Rhabditida) are promising biological control agents for the control of soil pests (GREWAL et al., 2001). Studies using EPNs have been carried out in some countries with other species of the genus Diabrotica and have presented good results under both laboratory and field conditons

¿Universidade de São Paulo/USP - Escola Superior de Agricultura "Luiz de Queiroz"/ESALQ - Departamento de Entomologia e Acarologia - Avenida Pádua Dias - 11 - Cx. P. 9 - 13418-900 - Piracicaba - SP - Brasil - vsantosvivi@gmail.com

2Universidade Federal de Lavras/UFLA - Departamento de Entomologia/DEN - Lavras - MG - Brasil

${ }^{3}$ Universidade Federal de Viçosa/UFV - Departamento de Biologia Animal/DBA - Viçosa - MG - Brasi

"Universidade de São Paulo/USP - Escola Superior de Agricultura "Luiz de Queiroz"/ESALQ - Departamento de Ciência Exatas/LCE - Piracicaba - SP - Brasil

Ciênc. agrotec., Lavras, v. 35, n. 6, p. 1149-1156, nov./dez., 2011 
(JACKSON; BROOKS, 1989; WRIGHT et al., 1993; JOURNEY; OSTLIE, 2000; KURTZ et al., 2007).

The objective of this work was to evaluate the virulence of native and exotic entomopathogenic nematode isolates against of $D$. speciosa under laboratory and greenhouse conditions.

\section{MATERIAL AND METHODS}

The research was conducted at the Insect Pathology Laboratory and greenhouse of the Entomology Department (END) of the Federal University of Lavras (UFLA), located in the county of Lavras, MG, from December, 2007 to December, 2008.

\section{Rearing of Diabrotica speciosa and multiplication of entomopathogenic nematodes}

For the maintenance of adults and the obtaining of eggs and larvae of $D$. speciosa, the modified methodology described by Ávila and Milanez (2004) was used. Adults of $D$. speciosa were collected from bean crops in an experimental field of UFLA and from the Palmital Farm, in the municipal district of Ijaci, MG.

Adults were kept in cylindrical glass jars $17 \mathrm{~cm}$ high and $10 \mathrm{~cm}$ in diameter, with a perforated plastic cover, in an acclimatized chamber (temperature $25 \pm 1^{\circ} \mathrm{C}$, humidity $70 \pm 10 \%$ and 14 hour photophase).

The jars were lined with a disk of paper towel to avoid excess humidity. Bean leaves were placed within the jars to feed the insects, as well as a $5 \mathrm{~cm}$ diameter Petri dish containing a piece of black colored moistened gauze, to provide a surface for oviposition. On the surface of the gauze seminal rootlets of corn were placed to stimulate the oviposition of the females.

The eggs were removed from the oviposition substrate, by washing the gauze in running water over a fine fabric (voile), where they were retained. To avoid the contamination by fungi during the incubation period, the eggs were treated with a $1 \%$ copper sulfate (CuSO4) solution for two minutes and, soon afterwards, transferred to $9 \mathrm{~cm}$ diameter Petri dishes lined with humid filter paper, which were maintained in an acclimatized chamber $\left(25 \pm 1^{\circ} \mathrm{C}, 70 \pm 10 \%\right.$ humidity and 14 hour photophase) until the larvae hatched.

The larvae were maintained in plastic pots containing vermiculite and corn seedlings according to the methodology described by Ávila et al. (2000) until the beginning of the experiments.

Multiplication of EPNs was conducted using five larvae of Galleria mellonella Linnaeus (Lepidoptera: Pyralidae) raised in the laboratory, according to the methodology described by Dutky et al. (1964) and fed with a modified artificial diet (C. Dolinski, personal communication, March, 2008). The nematodes were multiplied according to the methodology described by Molina and López (2001).

\section{Virulence test of entomopathogenic nematodes to third instar larvae of Diabrotica speciosa}

The virulence against $D$. speciosa larvae of the seventeen isolates of EPNs, belonging to the genera Heterorhabditis and Steinernema was evaluated. The bioassay consisted of five repetitions, each made up of a 9 $\mathrm{cm}$ Petri dish containing $15 \mathrm{~g}$ of vermiculite, $1.5 \mathrm{~g}$ of corn roots and $9 \mathrm{~mL}$ of water, to which were transferred ten third instar D. speciosa larvae.

The experimental design was entirely random, with eighteen treatments (17 EPNs isolates and the control). 1 $\mathrm{mL}$ of aqueous suspension of EPNs was added at a concentration of 1500 infective juveniles (IJ)/mL, corresponding to $150 \mathrm{IJ} /$ insect, while $1 \mathrm{~mL}$ of distilled water was added to the control. The Petri dishes were maintained under controlled conditions at $25 \pm 1^{\circ} \mathrm{C}, 70 \pm 10 \%$ humidity and with a 14 hour photophase.

The evaluations were conducted three days after the application of the nematodes, by counting the number of dead larvae. The symptomatology of the dead larvae was verified by the confirmation of the causa mortis, according to the typical characteristics of death caused by nematodes. The larvae killed by nematodes of the genus Heterorhabditis presented a red color, while for Steinernema spp. they were of a whitish color.

The mortality data was submitted to the variance analysis and compared, by the Scott-Knott test of averages, to $5 \%$ probability using the SISVAR (FERREIRA, 2002) statistical program.

\section{Test with eggs}

The bioassay consisted of five repetitions, each made up of a $5 \mathrm{~cm}$ diameter Petri dish lined with a sheet of filter paper, to which ten five-day-old eggs of $D$. speciosa were transferred.

The experimental design was fully randomized. An aqueous suspension of $0.3 \mathrm{~mL}$ of the EPN isolates Heterorhabditis sp. RSC01 and S. glaseri were added to the Petri dish, at concentrations of 25, 50, 100, 150, 200 and 250 IJ/ insect. $0.3 \mathrm{~mL}$ of distilled water was added to the control and every other day, $0.25 \mathrm{~mL}$ of distilled water was added to each of the Petri dishes, to maintain humidity levels. The Petri dishes were maintained under controlled conditions at a temperature of $25 \pm 1^{\circ} \mathrm{C}, 70 \pm 10 \%$ humidity and with a 14 hour photophase. Daily evaluations were made by counting the larvae that had emerged from the eggs in each repetition. 
The data on egg mortality, obtained at different concentrations were submitted to the regression analysis at $5 \%$ of probability, using the SISVAR statistical program, with the mortality of the insect as the dependent variable and the concentrations of the nematode as the independent variable.

\section{Test with third instar larvae}

The test consisted of five replicates, each made up of a $9 \mathrm{~cm}$ diameter Petri dish, containing $15 \mathrm{~g}$ of vermiculite, $1.5 \mathrm{~g}$ of corn roots and $9 \mathrm{~mL}$ of distilled water, to which ten third instar $D$. speciosa larvae were transferred. The experimental design was fully randomised. $1 \mathrm{~mL}$ of aqueous suspension of EPN Heterorhabditis sp. isolate RSC01 and $S$. glaseri were added at the concentrations of 50,100, 150, 200, 250 and $300 \mathrm{IJ}$ per insect and, $1 \mathrm{~mL}$ of distilled water was added to the control. The Petri dishes were maintained under controlled conditions at $25 \pm 1^{\circ} \mathrm{C}, 70 \pm 10 \%$ humidity and with a 14 hour photophase. The evaluations were made three days after the start of the experiment, by counting the dead larvae in each repetition.

\section{Test with pupae}

The bioassay consisted of four repetitions, each made up of a $9 \mathrm{~cm}$ diameter Petri dish containing $15 \mathrm{~g}$ of vermiculite and $9 \mathrm{~mL}$ of distilled water, to which eight $D$. speciosa pupae were transferred. The experimental design was fully randomized. $1 \mathrm{~mL}$ of aqueous suspension of EPNs/ Petri dish was added at the concentrations of 100, 150, 200, 250 and $300 \mathrm{IJ} /$ insect of the Heterorhabditis sp. RSC01 isolates. $1 \mathrm{~mL}$ of distilled water/Petri dish was added to the control. The Petri dishes were maintained under controlled conditions at a temperature of $25 \pm 1^{\circ} \mathrm{C}, 70 \pm 10 \%$ humidity and with a 14 hour photophase. The evaluations were conducted three days after the start of the experiment, by counting the pupae killed by nematodes in each repetition. The pupae mortality caused by nematodes was confirmed by observing the symptomatology, since the pupae killed by Heterorhabditis sp. RSC01 presented a red coloration.

\section{Effect of temperature on the mortality of Diabrotica speciosa larvae by entomopathogenic nematodes}

A bioassay was conducted to study the effect of temperature on the infectivity of IJ, using the Heterorhabditis sp. RSC01 and S. glaseri nematodes. The bioassays consisted of five repetitions/ treatment, each made up of a $9 \mathrm{~cm}$ diameter Petri dish containing $15 \mathrm{~g}$ of sterilized vermiculite, $1.5 \mathrm{~g}$ of corn roots and $9 \mathrm{~mL}$ of distilled water, to which eight third instar D. speciosa larvae were transferred. The treatments were run at the constant temperatures of $15,20,22,25$ and $28^{\circ} \mathrm{C}$, in five acclimatized chambers, in which the Petri dishes remained for three days, with $70 \pm 10 \% \mathrm{RH}$ and a 12 hour photophase. $1 \mathrm{~mL}$ of standardized aqueous suspension was added at the concentration of $200 \mathrm{IJ} / \mathrm{insect}$, which was the concentration that caused the highest mortality of $D$. speciosa larvae, according to tests conducted under laboratory conditions. The experimental design was entirely random.

Evaluations were made three days after the start of the experiments, by counting the larvae killed EPNs in each repetition.

Mortality data (larvae and pupae) at different tested concentrations of the infective juveniles or different temperatures were compared using generalized linear models (GLM) with logit link function and binary distribution, using the Statistical Analysis System (SAS) (SAS INSTITUTE, 2003).

\section{Susceptibility of $D$. speciosa larvae to entomopathogenic nematodes under greenhouse conditions}

The bioassay consisted of six repetitions, each made up of a plastic vase with 2.5 liter capacity, containing sterilized soil and sterilized vermiculite medium (1/10) and $500 \mathrm{~mL}$ of distilled water. Eight corn seeds were sowed in each vase, which were thinned after seven days, leaving only five plants per vase. Twenty third instar D. speciosa larvae were transferred to each vase.

The larvae were placed at a depth of five centimeters below the soil level, close to the plant roots. Twenty-four hours after the larvae were transferred, $50 \mathrm{~mL}$ of EPNs aqueous suspension were added, at the concentrations of 6,500, 13,000, 26,000 and 52,000 IJ of Heterorhabditis sp. RSC01, per repetition (vase). The vases corresponding to the control received $50 \mathrm{~mL}$ of distilled water. The concentration of 6,500 IJ/vase was established according to laboratory test results that determined the maxim lethal concentration of Heterorhabditis sp. RSC01 on third instar D. speciosa larvae. The experimental design was entirely random.

The average temperature registered during the experiment was $27.4^{\circ} \mathrm{C}$ and the average relative humidity $62 \%$. The evaluations were conducted five days after the start of the experiment, by counting the live larvae per each repetition. The survival data was submitted to the variance analysis and the averages were compared by the Tukey test at 5\% probability, using the SISVAR statistical program.

\section{RESULTSAND DISCUSSION}

\section{Virulence test}

All of the tested nematodes caused mortality to third instar D. speciosa larvae, differing from the control, in which mortality was not observed. However, the virulence varied among the different isolates (Table 1). 
Table 1 - Percentage mortality of third instar larvae of Diabrotica speciosa by different isolates of entomopathogenic nematodes at a concentration of $150 \mathrm{IJ} /$ insect. (Temp.: $25 \pm 1^{\circ} \mathrm{C}, \mathrm{RH}: 70 \pm 10 \%$ and photophase: $14 \mathrm{~h}$ ).

\begin{tabular}{ccc}
\hline Treatment (EPN isolates) & Place of Origin & Average Mortality \pm EP $(\%)^{1}$ \\
\hline Heterorhabditis sp. RSC01 & Amazonas/ Brasil & $94 \pm 2.34 \mathrm{a}$ \\
Steinernema glaseri CCA & Sao Paulo/ Brasil & $84 \pm 3.66 \mathrm{a}$ \\
Heterorhabditis sp. JPM04 & Minas Gerais/ Brasil & $82 \pm 2.89 \mathrm{a}$ \\
Heterorhabditis amazonensis RSC05 & Amazonas/ Brasil & $78 \pm 3.61 \mathrm{a}$ \\
Heterorhabditis sp. RSC02 & Amazonas/ Brasil & $74 \pm 4.68 \mathrm{~b}$ \\
Heterorhabditis bacteriophora & New Jersey/ USA & $72 \pm 2.89 \mathrm{~b}$ \\
Heterorhabditis sp. JPM03 & Minas Gerais/ Brasil & $72 \pm 2.89 \mathrm{~b}$ \\
Heterohabditis sp. RSC03 & Amazonas/ MG & $70 \pm 3.76 \mathrm{~b}$ \\
Heterorhabditis sp. ALHO & Minas Gerais/ Brasil & $68 \pm 3.61 \mathrm{~b}$ \\
Heterorhabditis sp. PI & Piaui/ Brasil & $68 \pm 439 \mathrm{~b}$ \\
Steinernema feltiae SN & Florida/ USA & $66 \pm 2.99 \mathrm{~b}$ \\
Steinernema carpocapsae A11 & North Carolina/ USA & $64 \pm 4.55 \mathrm{~b}$ \\
Heterorhabditis sp. SORGO & Minas Gerais/ Brasil & $56 \pm 2.99 \mathrm{~b}$ \\
Steinernema anomali & Voronezh/ Russia & $54 \pm 4.42 \mathrm{~b}$ \\
Heterorhabditis sp. JPM01 & Minas Gerais/ Brasil & $46 \pm 2.34 \mathrm{c}$ \\
Heterorhabditis sp. HP88 & New Jersey/ USA & $38 \pm 4.66 \mathrm{c}$ \\
Steinernema riobrave 355 & Texas/ USA & $30 \pm 3.98 \mathrm{c}$
\end{tabular}

${ }^{1}$ Averages followed by same letter do not differ by Scott-Knott test $(\mathrm{p}<0.05)$.

Among the seventeen isolates tested, fourteen caused over $50 \%$ mortality of $D$. speciosa larvae. The most virulent were the isolates Heterorhabditis sp. RSC01 (94\%), S. glaseri (84\%), Heterorhabditis sp. JPM04 (82\%) and Heterorhabditis amazonensis RSC05 (78\%) (Table 1).

These results are similar to those observed by Toepfer et al. (2005) who, while working with the isolate $S$. glaseri NC (USA origin), saw that this was pathogenic to third instar larvae of Diabrotica virgifera virgifera LeConte, 1868 (Coleoptera: Chrysomelidae) under laboratory conditions. Converse and Grewal (1998), seeking to select EPNs for the control of Cyclocephala hirta LeConte, 1861 (Coleoptera: Scarabaeidae), verified that isolate NJ65 of S. glaseri was the most virulent among the 22 isolates tested, causing $76.5 \%$ larval mortality under laboratory conditions, after three days of exposure to IJ.

It may be noticed that the most virulent nematodes are from Brazil (Table 1). In addition, native isolates have better chances of adaptation to the Brazilian environmental conditions, as well as to the local insect fauna (DOLINSKI; MOINO Jr., 2006).

In this research, several native isolates were used and they showed potential for the control of D. speciosa larvae. These should also be investigated regarding their specificity, to commercially exploit only those that present a high selectivity to the natural enemies (DOLINSKI; MOINOJR., 2006).

\section{Test with eggs}

There was no effect of the nematodes Heterorhabditis sp. RSC01 and S. glaseri on the mortality of $D$. speciosa eggs at any of the tested concentrations.

These results are similar to those related by Jackson and Brooks (1995) who, working with $D$. v. virgifera, did not verify an effect of the nematode $S$. carpocapsae on the mortality of eggs of this insect, under laboratory conditions. Journey and Ostlie (2000), testing S. carpocapsae for the control of $D$. v. virgifera in the field, also verified that this isolate did not present an egg viability reduction.

According to Jackson and Brooks (1995), the absence of infectivity of EPNs in crisomelid beetle eggs can be related to the impermeability of the eggs of those organisms. Toepfer and Kuhlmann (2004) related the natural occurrence of native EPNs in D. v. virgifera eggs in Central Europe, however, the identification of the isolates was not conducted. 
Those results differ from those observed by Machado et al. (2005) who, working with Mygdolus fryanus Westwood, 1863 (Coleoptera: Vesperidae) verified 53.33\% egg mortality, inoculating $60 \mathrm{IJ} /$ egg of Heterorhabditis indica Poinar, Karunakar and David 1992, not differing from the concentration of $600 \mathrm{IJ} / \mathrm{egg}(60 \%)$.

\section{Tests with third instar larvae}

The mortality of larvae caused by Heterorhabditis sp. RSC01 varied between 64 and 96\% (Table 2), at the concentrations of 50 and $300 \mathrm{IJ} /$ insect and between 34 and $90 \%$, at the concentrations of 50 and $200 \mathrm{IJ} /$ insect, respectively, when applying $S$. glaseri.

Table 2 - Percentage of confirmed mean mortality of larvae of Diabrotica speciosa at different concentrations of infective juveniles of Heterorhabditis sp. RSC01 and Steinernema glaseri (temperature $25 \pm 1^{\circ} \mathrm{C}, \mathrm{RH} 70 \pm 10 \%$ and of 14 hour photophase).

\begin{tabular}{ccc}
\hline \multirow{2}{*}{ Treatment } & \multicolumn{2}{c}{ Mean mortality (\%) \pm Standard Error Mean $^{1}$} \\
\cline { 2 - 3 } (JI/ larvae) & $\begin{array}{c}\text { Heterorhabditis } \\
\text { sp. RSC01 }\end{array}$ & $\begin{array}{c}\text { Steinernema } \\
\text { glaseri }\end{array}$ \\
\hline 0 & $0 \mathrm{~d}^{1}$ & $2 \pm 2 \mathrm{c}$ \\
50 & $64 \pm 6.8 \mathrm{c}$ & $34 \pm 6.7 \mathrm{~b}$ \\
100 & $82 \pm 5.4 \mathrm{bc}$ & $70 \pm 6.5 \mathrm{ab}$ \\
150 & $86 \pm 4.9 \mathrm{ab}$ & $74 \pm 6.2 \mathrm{ab}$ \\
200 & $92 \pm 3.8 \mathrm{ab}$ & $90 \pm 4.2 \mathrm{a}$ \\
250 & $88 \pm 4.6 \mathrm{ab}$ & $80 \pm 5.7 \mathrm{a}$ \\
300 & $96 \pm 2.8 \mathrm{a}$ & $88 \pm 4.6 \mathrm{a}$ \\
\hline
\end{tabular}

${ }^{1}$ Means followed by the same letter do not differ at $5 \%$ probability when compared to generalized linear models.

The maximum mortality of $D$. speciosa larvae by Heterorhabditis sp. RSC01 was observed at a concentration of $300 \mathrm{IJ} /$ insect, corresponding to $47.16 \mathrm{IJ} /$ $\mathrm{cm}^{2}$. In the bioassay of $S$. glaseri the highest mortality was observed at the concentration of $200 \mathrm{IJ} /$ insect $\left(31.44 / \mathrm{cm}^{2}\right)$.

Toepfer et al. (2005), testing the virulence of $S$. glaseri on third instar larvae of $D$. v. virgifera at different concentrations, verified that there was an increase in the mortality of larvae with the increase of the concentration, observing a mortality superior to $77 \%$ at the concentration of $15.9 \mathrm{IJ} / \mathrm{cm}^{2}$. These results are similar to those observed by Kurtz et al. (2009) who reported that when testing $H$. bacteriophora, $H$. megidis and $S$. feltiae at a concentration of $16 \mathrm{IJ} / \mathrm{cm}^{2}$ in trays with sand, they observed the maximum mortality of the third instar larvae (87.8\%) in the treatment with $H$. bacteriophora.

\section{Tests with pupae}

The Heterorhabditis sp. RSC01 isolate was pathogenic to pupae of $D$. speciosa, causing mortality at all of the studied concentrations (Table 3). Concentrations of 200, 250 and $300 \mathrm{IJ} /$ insect did not differ among themselves and caused high mortality of $D$. speciosa pupae.

Table 3 - Percentage of confirmed mean mortality of pupae of Diabrotica speciosa at different concentrations of infective juveniles of Heterorhabditis sp. RSC01 isolate $\left(25 \pm 1^{\circ} \mathrm{C}, \mathrm{RH} 70 \pm 10 \%\right.$ and a photophase of 14 hours $)$.

\begin{tabular}{cc}
\hline $\begin{array}{c}\text { Treatment } \\
(\mathrm{J} / \text { pupae })\end{array}$ & $\begin{array}{c}\text { Mean mortality }(\%) \pm \\
\text { Standard Error Mean }\end{array}$ \\
\hline 0 & $18.75 \pm 6.9 \mathrm{~b}^{1}$ \\
100 & $75 \pm 7.6 \mathrm{ab}$ \\
150 & $68.75 \pm 8.1 \mathrm{ab}$ \\
200 & $7.50 \pm 5.8 \mathrm{a}$ \\
250 & $93.75 \pm 4.3 \mathrm{a}$ \\
300 & $93.75 \pm 4.3 \mathrm{a}$ \\
\hline
\end{tabular}

${ }^{1}$ Means followed by the same letter do not differ at $5 \%$ probability when compared to generalized linear models.

Yang et al. (2003), working with $S$. feltiae for the control Luperomorpha suturalis Chen, 1938 (Coleoptera: Chrysomelidae), verified pupae mortality of 97.1 and $83 \%$, under laboratory conditions, at a temperatures of 25 and $15^{\circ} \mathrm{C}$, respectively.

The effect of the nematodes on the D. speciosa pupae can increase the long term action of these entomopathogens in the reduction of field populations of this insect, interfering in population growth and, consequently, avoiding re-infestations by the pest. Furthermore, the reduction of the adult population in the field can contribute to the reduction of the damage that these insects cause to the aerial part of the plants.

\section{Effect of Temperature on the Mortality of Larvae of $D$. speciosa by Entomopathogenic Nematodes}

At $20^{\circ} \mathrm{C}$ we observed a low mortality of larvae in both treatments (S. glaseri and Heterorhabditis sp. RSC01) (Table 4). To Heterorhabditis sp. RSC01 at the temperatures of 25 and $28^{\circ} \mathrm{C}$ we verified high mortality of larvae, and no mortality was observed at $15^{\circ} \mathrm{C}$.

The bioassay of $S$. glaseri, at temperatures of 22 and $25^{\circ} \mathrm{C}$ caused high mortality of larvae, whereas at $28^{\circ} \mathrm{C}$ there was a reduction in mortality, suggesting that this nematode may be more sensitive to high temperatures. 
These results are in accordance with those observed by Boivin and Belair (1989) who, working with S. feltiae for the control of Listronatus oregonensis LeConte, 1857 (Coleoptera: Curculionidae), verified a decrease in $\mathrm{TL}_{50}$ with the increase of the temperature.

Table 4- Percentage of confirmed mean mortality of larvae of Diabrotica speciosa by Heterorhabditis sp. RSC01 and Steinernema glaseri isolates at different temperatures (RH $70 \pm 10 \%$ and of 14 hour photophase).

\begin{tabular}{ccc}
\hline \multirow{2}{*}{$\begin{array}{c}\text { Treatment } \\
\left({ }^{\circ} \mathrm{C}\right)\end{array}$} & \multicolumn{2}{c}{$\begin{array}{c}\text { Mean mortality }(\%) \pm \text { Standard Error Mean } \\
\text { sp. RSC01 }\end{array}$} \\
\hline 15 & $0 \mathrm{c}^{1}$ & $\begin{array}{c}\text { Steinernema } \\
\text { glaseri }\end{array}$ \\
20 & $17.50 \pm 6 \mathrm{~b}$ & $5 \pm 3.4 \mathrm{c}$ \\
22 & $60 \pm 7.7 \mathrm{ab}$ & $58.33 \pm 10.06 \mathrm{bc}$ \\
25 & $82.50 \pm 6 \mathrm{a}$ & $62.50 \pm 7.6 \mathrm{a}$ \\
28 & $85 \pm 5.6 \mathrm{a}$ & $47.50 \pm 7.9 \mathrm{ab}$ \\
\hline
\end{tabular}

${ }^{1}$ Means followed by the same letter do not differ at $5 \%$ probability when compared to generalized linear models.

Temperature is the main factor that interferes in the mobility of the nematodes and, consequently, in the expense of their nutritional reserves and in the survival of IJ (MOLYNEUX, 1985). The reduction in the mortality of $D$. speciosa larvae at the lowest temperatures, for both isolates tested, is a factor that should be taken into account when employing this entomopathogen in the field, keeping in mind its wide territorial distribution and the different climatic conditions in the areas in which this insect is found. In colder environments, insect mortality over a short period of time could be affected.

\section{Susceptibility of $D$. speciosa Larvae to Entomopathogenic Nematodes under Greenhouse conditions}

The Heterorhabditis sp. RSC01 nematode reduced the survival of $D$. speciosa larvae in the soil at all of the tested concentrations, when compared to the control, without, however, differing among themselves (Figure 1).

The non-verification of mortality differences of $D$. speciosa larvae among the four tested concentrations demonstrates evidence that the concentration of 6,500 IJ was sufficient to cause the maximum mortality in the greenhouse, the use of higher concentrations being unnecessary under this condition.

These results are similar to those observed by Riga et al. (2001). Testing the efficiency of the $S$. glaseri and $S$. feltiae nematodes against four species of corn pests, among them crisomelid beetle larvae, under laboratory and greenhouse conditions, these authors verified that both tested species presented an effect on the mortality of all of the pest species, resulting in lower damage incidence in the corn plants in the parcels that received the EPN treatments in relation to the control.

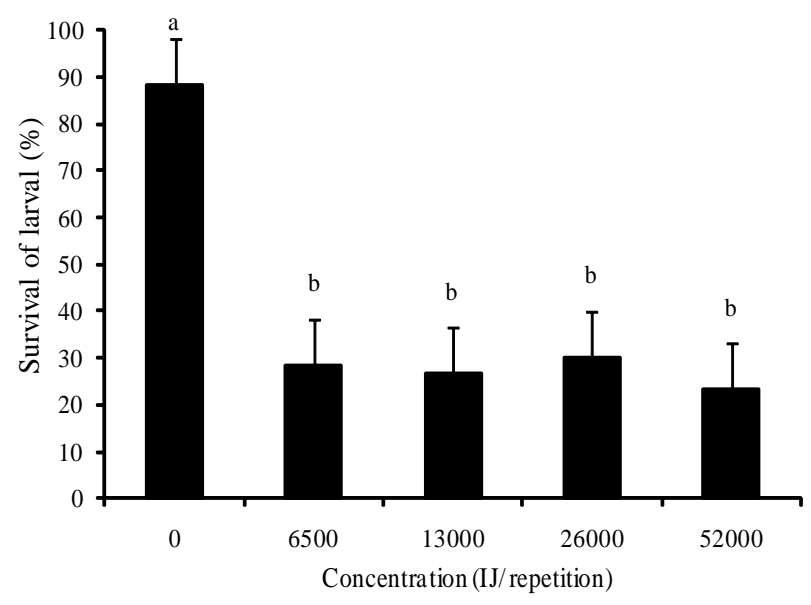

Figure 1 - Average percentage survival of Diabrotica speciosa larvae at different concentrations of infective juveniles of Heterorhabditis sp. RSC01 per pot, under greenhouse conditions.

The concentration of Heterorhabditis sp. RSC01 that caused the maximum mortality of $D$. speciosa larvae under laboratory and greenhouse conditions (31.41 IJ/ $\mathrm{cm}^{2}$, equivalent to $3.14 \times 10^{9} \mathrm{IJ} / \mathrm{ha}$ ) is similar to the concentration used by Yang et al. (2003) that studied $S$. feltiae for the control of $L$. suturalis in the field and verified $77.8 \%$ larval reduction at the concentration of $30 \mathrm{IJ} / \mathrm{cm}^{2}$, thirty-eight days after the treatment and $92.4 \%$ larval reduction a hundred days after the treatment. Wright et al. (1993), working with S. carpocapsae applied in the field for the control of $D$. v. virgifera, under center pivot irrigation in the corn culture, observed reduction in the damage rate of the plants. They also noticed a reduction in adult emergence, with nematode application at concentrations of 1.2 and $2.5 \mathrm{x}$ $10^{9} \mathrm{IJ} / \mathrm{ha}$, lower that mentioned in this research. Likewise, Thurston and Yule (1990), testing the nematodes $S$. feltiae All and S. bibionis Sn against D. barberi larvae in the field, in corn culture, observed that both species of EPNs tested reduced the number of larvae in the soil compared to the control, at concentrations of $1.3 \times 10^{8}$ 
and $1.3 \times 10^{9} \mathrm{IJ} / \mathrm{ha}$, not verifying a difference among the species or the tested concentrations.

Toepfer et al. (2008), working with EPNs for the control of $D$. $v$. virgifera larvae under field conditions in the corn culture, verified that all of the species of nematodes (H. bacteriophora, S. feltiae and H. megidis) tested caused reduction of the insect population in the soil. However, the most virulent species was $H$. bacteriophora, that caused an $81 \%$ reduction. The same authors also verified that the tested species reduced the percentage of damage to the plants, proving the potential of EPNs for the control of crisomelid beetle larvae in corn culture.

Kurtz et al. (2007) also demonstrated that the $H$. bacteriophora, H. megidis and S. feltiae species present a capacity to establish themselves in corn for a period of up to five months, being promising for the control of $D$. $v$. virgifera in this culture, with massive applications of those EPNs in the field.

\section{CONCLUSION}

The high potential that EPNs demonstrate in laboratory, greenhouse and field studies in the control of crisomelid beetle larvae, as well as the results obtained in this study from laboratory and greenhouse tests, confirms the great potential of Heterorhabditis sp. RSC01 for the control of $D$. speciosa larvae. Their use can be viable in field studies seeking the control of this pest in such cultures as irrigated corn and, in particular potato as it is cultivated in smaller areas, requiring high moisture levels for its development, a characteristic that favors the survival and behavior of EPNs.

\section{ACKNOWLEDGMENTS}

To Professor Magno Antonio Patto Ramalho, of the Departamento de Biologia da Universidade Federal de Lavras, for the availability of areas cultivated with beans for the insect collection. To Doctor Luiz Garrigós Leite, of the Instituto Biológico de São Paulo, for suggestions on the manuscript. To CAPES for the Master's grant to the first author.

\section{REFERENCES}

ÁVILA, C.J.; MILANEZ, J.M. Larva-alfinete. In: SALVADORI, J.R.; ÁVILA, C.J.; SILVA, M.T.B. Pragas de solo no Brasil. Passo Fundo: Embrapa Trigo, 2004, p.211-232.

ÁVILA, C.J.; TABAI, A.C.P.; PARRA, J.R.P. Comparação de técnicas para a criação de Diabrotica speciosa (Germar) (Coleoptera: Chrysomelidae) em dietas natural e artificial. Anais da Sociedade Entomológica do Brasil, Londrina, v.29, n.2, p.257-267, jun. 2000.

BOIVIN, G; BELAIR, G. Infectivity of two strains of Steinernema feltiae (Rhabditida: Steinernematidae) in relation to temperature, age, and sex of carrot weevil (Coleoptera: Curculionidae) adults. Annals of the

Entomological Society of America, Lanham, v.82, n.3, p.762765, jun. 1989.

CONVERSE, V.; GREWAL, P.S. Virulence of entomopathogenic nematodes to the western masked chafer Cyclocephala hirta (Coleoptera: Scarabaeidae). Journal of Economic Entomology, Lanham, v.91, n.2, p.428432, apr. 1998.

\section{DOLINSKI, C.; MOINOJÚNIOR,A. Utilização de} nematóides entomopatogênicos nativos ou exóticos: o perigo das introduções. Nematologia Brasileira, Brasília, v.30, n.2, p.139-149, 2006.

\section{DUTKY,S.R.;THOMPSON, J.V.; CANTWELL, GE. A} technique for the mass propagation of the DD-136 nematode. Journal of Insect Pathology, San Diego, v.6, n.4, p.417-422, 1964.

\section{FERREIRA, D. F. SISVAR Sistemas de Análises de} Variância para dados balanceados: programa de análises estatísticas e planejamento de experimentos. Versão 4.3. Lavras: UFLA, 2002.

\section{GASSEN, D.N. Insetos subterrâneos prejudiciais às culturas no sul do Brasil. Passo Fundo: EMBRAPA-CNPT, 1989, 49 p. (Documentos, 13).}

GREWAL, P.S.; NARDO, E.A.B.; AGUILLERA, M.M. Entomopathogenic nematodes: potential for exploration and use in South America. Neotropical Entomology, Londrina, v.30, n.2, p.191-205, jun. 2001.

JACKSON, J.J.; BROOKS, M.A. Susceptibility and immune response of western corn rootworm larvae (Coleoptera: Chrysomelidae) to the entomogenous nematode, Steinernema feltiae (Rhabditida: Steinernematidae). Journal of Economic Entomology, Lanham, v.82, n.4, p.1073-1077, aug. 1989.

JACKSON, J.J.; BROOKS, M.A. Parasitism of western corn rootworm larvae and pupae by Steinernema carpocapsae. Journal of Nematology, Lakeland, v.27, n.1, p.15-20, mar. 1995. 
JOURNEY, A.M.; OSTLIE, K.R. Biological control of the western corn rootworm (Coleoptera:Chrysomelidae) using the entomopathogenic nematode, Steinernema carpocapsae. Environmental Entomology, Lanham, v. 29, n.4, p.822-831, aug. 2000.

KURTZ, B. et al. Assessment of establishment and persistence of entomopathogenic nematodes for biological control of western corn rootworm. Journal of Applied Entomology, Berlin, v.131, n.6, p.420-425, jul. 2007.

KURTZ, B. et al. Comparative susceptibility of larval instars and pupae of the western corn rootworm to infection by three entomopathogenic nematodes.

BioControl, Dordrecht, v.54, n. 2, p. 255-262, apr. 2009.

MACHADO, L.A. et al. Patogenicidade de nematóides entomopatogênicos a ovos e larvas de Migdolus fryanus (Westwood, 1863) (Coleoptera: Vesperidae). Arquivos do Instituto Biológico, São Paulo, v.72, n.2, p.221-226, abr./jun. 2005.

MOLINA, J.P.; LÓPEZ, N.J.C. Producción in vivo de tres entomonematodos com dos sistemas de infección em dos hospedantes. Revista Colombiana de Entomología, Bogotá, v.27, n.1-2, p.73-78, ene./jun, 2001.

MOLYNEUX, A.S. Survival of infective juveniles Heterorhabditis spp., and Steinernema spp. (Nematoda: Rhabditida) at various temperatures and their subsequent infectivity for insects. Revue Nematology, v.8, n.2, p.165-170, 1985.

RIGA, E.; WISTLECRAFT, J.; POTTER, J. Potential of controlling insect pests of corn using entomopathogenic nematodes. Canadian Journal of Plant Science, Ottawa, v.81, n.4, p.783-787, oct. 2001.
SAS INSTITUTE. SAS/ Stat 9.23 Service Pack 2. Cary, 2003.965p.

THURSTON, G.S.; YULE, W.N. Control of larval northern corn rootworm (Diabrotica barberi) with two Steinernematid nematode species. Journal of Nematology, Lakeland, v.22, n.1, p.127-131, jan. 1990.

TOEPFER, S.; KUHLMANN, V. Survey for natural enemies of the invasive alien chrysomelid, Diabrotica virgifera virgifera, in Central Europe. BioControl, Dordrecht, v.49, n.5, p.385-395, aug. 2004.

TOEPFER, S. et al. Screening of entomopathogenic nematodes for virulence against the invasive western corn rootworm, Diabrotica virgifera virgifera (Coleoptera: Chrysomelidae) in Europe. Bulletin of Entomological Research, London, v.95, n.5, p.473-482, oct. 2005.

TOEPFER, S. et al. Comparative assessment of the efficacy of entomopathogenic nematode species at reducing western corn rootworm larvae and root damage in maize. Journal of Applied Entomology, Berlin, v.132, n.5, p.337-348, jun. 2008.

WRIGHT, R.J. et al. Efficacy and persistence of Steinernema carpocapsae (Rhabditida: Steinernematidae) applied through a center-pivot irrigation system against larval corn rootworms (Coleoptera: Chrysomelidae). Journal of Economic Entomology, Lanham, v.86, n.5, p.1348-1354, oct. 1993.

YANG, X. et al. Evaluation of entomopathogenic nematodes for control of the beetle, Luperomorpha suturalis Chen (Col., Chrysomelidae). Journal of Applied Entomology, Berlin, v.127, n.7, p.377-382, aug. 2003. 